\title{
From Second National Communication to Third National Communication for the UNFCCC: Sri Lanka's Progress
}

\author{
Ranasinghe D.M.S.H.K. \\ Faculty of Graduate Studies, University of Sri Jayewardenepura, Sri Lanka \\ hemanthi.ranasinghe@gmail.com
}

\begin{abstract}
Sri Lanka is a signatory country to the United Nations Framework Convention on Climate Change (UNFCCC) and therefore is expected to provide information on greenhouse gas (GHG) inventories, measures to mitigate and to facilitate adequate adaptation to climate change, and any other information that the party considers relevant to the achievement of the objective of the Convention.Sri Lanka is now in the preparation of the $3^{\text {rd }}$ National Communication. This paper attempts to review the status of the implementation of the recommendations provided by the Second National Communication (submitted in 2010) in the area of Green House Gas mitigation in the backdrop of the expectations of the Third National Communication. The targets of Intended Nationally Determined Contributions (INDCs) were also considered in this context. The sectors dealt with here are power, transport, industries, agriculture, land use, land use change and forestry and waste. In general considerable action had been taken towards implementation of the recommendations put forward by the Second National Communication (2NC). However more work needs to be done to fulfil the expectations fully. With regards to the power sector, despite the expectation of the INDCs to provide $50 \%$ of the energy demand from Non-Conventional Renewable Energies (NCRE) by 2030, the Long Term Generation and Expansion Plan of the Ceylon Electricity Board envisages only $26.27 \%$ from NCRE by 2034 while the contribution from coal increased to $56.91 \%$. The recommendation of $2 \mathrm{NC}$ to introduce natural gas as an alternative for base load generation has not materialized. With regards to the transportation sector which emits about $50 \%$ of carbon dioxide, there had been certain policy directions towards ensuring sustainable transport modes but the progress is rather slow. Some strategies and action plans in this regard are National Transport Master Plan, Road Sector Master Plan and Western Megapolis Action Plan which collectively aims at enhancing the use of public transport of higher quality and encourage its use while constructing and maintaining high quality transport modes including road and rail. Clean Air 2025 and Blue Green Era directives also accentuates these intentions. Greening the industries remain largely voluntary. The Ministry of Mahaweli Development and Environment has introduced two very important tools; National Green Reporting System (2011) and Green Procurement Policy (2015). The Blue Green Era Policy advocates green infrastructure and green industries. In the area of agriculture, National Agriculture Policy Framework and National Food Production Programme (2016-18) identifies the requirement of production of safe food by promoting eco-friendly practices and minimizing agro chemicals and pesticides in food crop production. The policy on toxin free country also is in agreement to this. With regards to the land use, land use change and forestry, the major attempt is the production of the National REDD+ Investment Framework and Action Plan in 2017. It encompassed three policy areas; forest, wildlife and watersheds, land use planning and other forested lands. In the waste sector, while National Policy on Solid Waste Management (2007) and Pilisaru Project are struggling to achieve their objectives, plans are underway to form a single waste management authority for the country and also introduce instruments such as Polluter Pay, producer Responsible etc. to minimize the pollution from waste streams. A Waste Management Plan for target provinces had been prepared by the Ministry of Mahaweli Development and Environment with the assistance of UN HABITAT in 2017. There is some interest in waste to energy projects.
\end{abstract}

Keywords: National communication, Transport, Waste, Forests, Recommendations, Power

Proceedings of the $22^{\text {nd }}$ International Forestry and Environment Symposium 2017 of the Department of Forestry and Environmental Science, University of Sri Jayewardenepura, Sri Lanka 